\title{
Risk Management Design for Private, Small, and Medium Scale Musical Concerts
}

\author{
Harriman Samuel Saragih, Evo Sampetua Hariandja \\ Business School \\ Management Department \\ University of Pelita Harapan \\ Tangerang, Indonesia \\ harriman.saragih@uph.edu
}

\author{
Sukoyo \\ Faculty of Industrial Technology \\ Industrial Engineering Department \\ Institute of Technology Bandung \\ Bandung, Indonesia
}

\begin{abstract}
Risks are likely to become the factors that are lacking of attention in times of organizing events. According to the practical experiences and observations by the author in the field of private, small and medium musical shows and concerts, poor project planning coordination among the committee and lack of attention to possible risks are the factors that lead to bad impacts to the whole performance of the concert. The author sees that risk management framework enables the committee to gain the helicopter view of the overall planning in the event, from the initial to the post execution stage of a concert. The framework used in this study is risk management system based on AS/NZS 4360:2004 which provides comprehensive steps in determining and analyzing the possible risks in conducting a project. In this study, probability and severity of each possible risks using Delphi method to the experts of whom have the experience in the respective field of more than ten years. This risk management design is applied in the "Light up Our Children's Future" Charity Concert in Bandung on May 9th 2013. Upon the implementation in this concert, the committees were able to reach the success rate of $73 \%$, higher level of success compared to the previous homogeneous concerts which only resulted in the success rate of $54 \%$.
\end{abstract}

Keywords - music concert; risk management; AS/NZS 4360:2004; project management

\section{INTRODUCTION}

Project risk management is not limited to several industries only such as manufacturing, processing, construction or mining, but can also be applied to events such as wedding, sports competition, elections, conferences or musical concerts. All these events mentioned are categorized as projects as these events are limited by time, costs and performances. Events have different complexities and uncertainties compared to routine activities since project is unique and highly customized. On the other hand, events still need to be well prepared in facing these uncertainties. Good events are those which can execute the whole things as planned. The author has more than ten years of experiences in the field of musical concerts. Specifically, the concerts defined in this study are limited to private, small and medium scale concerts. In planning these types of concerts, the author sees that there are uncertainties need to be managed in the phase of planning, negotiation, procurement, scheduling, execution and post-execution. In these types of concerts, the author sees that mostly the committee has great focus on the musical aspects, while the other operational aspects are lacking attentions.

There were previous studies that discussed risk management in musical concerts. Ronchi [1] discusses several aspects in music festivals evacuation such as preventive evacuation of a section of the festival area that contains 15,000 people when fire breaking out on a ship; escalating scenario involving the total evacuation of the entire festival area which contains 65,000 people due to bomb threat; scenario involving the entire area of 65,000 people due to explosion threat by overheating ship engine. Carroll [2] also reported the event of Radiohead stage collapse in Toronto that left three injured and one dead in the live music concert event. The observable problems which are occurred in the previous observations are concerts of Classic Hymns and Glorify in 2010 to 2012 where the author was present on the concerts. The observations in school festivals at SMA Santa Angela and SMA Santo Aloysius in Indonesia, have some relevant historical events regarding potential risks in the musical concerts. For example, artists who came late to the event to conduct check sound; sound system that is not matched with the electrical specification which can cause electrical problem in the stages; welcoming the public and visitors. These are the few examples of risks occurred in the middle scale musical concerts recently. The author sees that these uncertainties need to be clearly addressed in order to manage the project well to the end.

"Light up Our Children's Future!" is a musical concert conducted in Sasana Budaya Ganesha which has seating capacity of approximately 3.000 seats. The study is conducted in this concert to contribute to the success rate of the event, and to minimize the operational risks that could possibly occurred to this event. This study will discuss the risk management framework of AS/NZS 4360:2004 which is sufficient to address the problem [3]. The author sees that risk management approach in musical concerts is still lacking of attention. Hence, it is expected that the risk management designed in this study will help this event to run with better success rate compared to previous homogeneous concerts. This study is expected to give preliminary insights, both in theoretical and practical, through risk management and basic project management principles that is applied in musical concerts. 


\section{LITERATURE REVIEW}

From time to time, most people interpret risk the same as uncertainties. However, these two words are different. The definition of risk has been evolving from time to time. Risk can be defined in several descriptions such as 'everything that is given from God which can be used for profit', unexpected outcomes either good or bad [4]. Scientifically, risks are identical with probability of an outcome. Allen [4] defines risks by four parameters which are susceptibility to change or external influences, probability of occurrence, severity of impact, and degree of interdependency with other factors of risk. The AS/NZS 4360:2004 framework defines risk as all outcomes which have impact to the objective of an event [3]. Uncertainties are defined as all situations which are impossible to be converted into quantitative measurements [5]. Uncertainties tend to have the meaning of every event that is impossible to predict and know, while risks are the outcomes that tend to have its probability to happen and the severity when it happens.

Generally, the source of risks can be classified to several factors such as politics, environments, market, economy, financial, nature, technical, regulation, human error, crime, security and legal [4]. These types of risks are general source of risks, meanwhile in the musical concert projects, the types of risks can be addressed more specific to several aspects. Venue, medical provisions, environmental safety, control and communication, stewarding, emergency planning, financial and human resources are the common risks that can affect the project [6]. Projects and events might have been understood differently among people. There are some definitions about project taken into consideration in this study such as "A project is usually a one-time activity with a well-defined set of desired end results" [7]. According to Oxford Dictionary, an event is "A thing that happens or takes place, especially one of importance" [8]. According to Audstone [9], "Event has an end date but usually no 'development cycle'. That is the event is culmination of work over time but all the effort goes into the final product. While there can be considerable preparation work to an event, there are no formal interim deliverables only interim milestones". Hence, according to the previous definitions, the author assumes that event is categorized as a one-time activity which has limitation on time, cost, and performance to achieve the desired set of end result. In general, events can be classified into leisure, cultural, personal and organizational events. In this study, events are categorized based on the total audiences. The author defines the events into four categories as shown in Table I.

TABLE I. CATEGORY OF EVENTS BY SiZE

\begin{tabular}{|l|l|}
\hline \multicolumn{1}{|c|}{ Event Category } & \multicolumn{1}{c|}{ Total Visitors } \\
\hline Private sized event & $<100$ visitors \\
\hline Small sized event & $100-1.000$ visitors \\
\hline Medium sized & $1.000-3.000$ visitors \\
\hline Large event & $>3.000$ visitors \\
\hline
\end{tabular}

Merna and Al-Thani [4] defines risk management as formal process which involve the identification, assessment, planning and management from every potential risks. According to AS/NZS 4360:2004, risk management is the process of identification regarding every potential outcome when conducting a planned task and to maximize positive outcomes and minimize negative outcomes and conduct improvements in every justifications and outcomes, as shown in Figure 1.

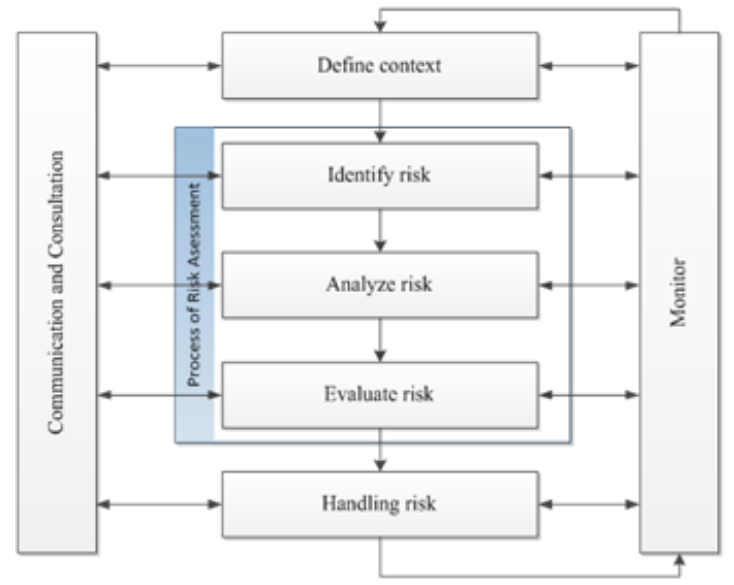

Fig. 1. Risk Management Framework based on AS/NZS 4360:2004 [4]

There are several risk management frameworks that can be applied to projects such as the Australian and New Zealand Standard 4360:2004, Enterprise Risk Management - Integrated Framework COSO 2004 (USA), The Canadian Standards Association Control Self-Assessment Q850, JSI Q 2001:2001, ISO 31000:2009 International Standard. In this study, AS/NZS 4360:2004 is used because of its simplicity and comprehensiveness. The philosophy of this framework is also to emphasize the importance of communication and consultation to every entities and individuals in the committees to conduct the concert properly.

\section{METHOD}

The study conducted qualitative and quantitative data to determine the risks, its probability and severity. Focus group is done to collect ideas, and discuss the options and outcomes in the music concerts. Not only focus group, interviews, brainstorming and observations are conducted in this study. Delphi method and probability-impact tables are used in the study to collect information and determine regarding the possible risks in the musical concert projects. Delphi method is used at the later stage to quantify the risks based on the probability and severity and used to gain the consensus decision from the experts. Using the definition from Oxford English Dictionaries "a person who is very knowledgeable about or skillful in a particular area" and Merriam Webster "having, involving, or displaying special skill or knowledge derived from training or experience", the experts on this study are the people who have more than ten years of experiences in organizing music concerts. Total of respondents in this study is twelve experts.

There are several steps need to be taken to conduct the Delphi Method starting from choosing the experts, create the assumptions and predictions, collect answers and analyze the results. If the result is agreed by the experts, then it will be used 
for further analysis, but if it is not, resend to the experts until the consensus answer is found. Probability impact table is one of the risk analysis tools that assess the relative importance on a risk according to two aspects: the probability of occurrence of the risk and its impact. In the process of quantification over any potential risk, several techniques can be carried out such as focus group discussions, interviews, brainstorming. In identifying a potential risk in terms of probability and impact, a standard need to be prepared so that the scoring of each of these risks can be consistent and objective from the beginning to the end. Upon collecting the data for the probability and impact of each risk, then the two variables are multiplied to collect the weight of the risk. The weight is used to determine the impact score of the risk ranging from very low to very high.

\section{ANALYSIS}

The event is organized by the internal committee which is divided into some divisions, illustrated in Table 2.

TABLE II. THE STRUCTURE OF THE COMMITTEE

\begin{tabular}{|l|l|}
\hline \multicolumn{1}{|c|}{ Division } & \multicolumn{1}{c|}{ Sub-Division } \\
\hline Directors & Chair, Project Manager, Operation Manager \\
\hline General Affairs & Secretary, Finance, Food \& Beverages \\
\hline Infrastructures & $\begin{array}{l}\text { Tools and equipment, security, documentation, } \\
\text { transportation }\end{array}$ \\
\hline Marketing & Marketing and publications \\
\hline Music and Creative & Main Event \\
\hline Pre-Event & Pre-Event \\
\hline
\end{tabular}

The committee conducted the coordination meeting once every week. Every leader of each division addressed the plan and problems in each meeting. Possible risks in the is used in the planning and discussions to prevent potential risks outcome. According to the six stages of organizing an event determined by the author, based on the interviews, discussions and observations, potential risks are determined in every stage. Every risks and severity are presented along with the responsible division. There are total 78 potential risks in organizing the event through the six steps. Table 3 illustrates the summary of the findings.

TABLE III. TOTAL POTENTIAL RISKS FROM EACH STAGES

\begin{tabular}{|l|l|l|l|}
\hline \multicolumn{1}{|c|}{ Stage } & \multicolumn{1}{|c|}{$\begin{array}{c}\text { Responsible } \\
\text { Divisions }\end{array}$} & $\begin{array}{l}\text { Total } \\
\text { Potential } \\
\text { Risks }\end{array}$ & Risk Levels \\
\hline Pre-Planning & Directors & 3 & Minor \\
\hline Planning & Directors & 2 & Moderate \\
\hline Organizing & Directors and Creative, & 34 & Minor, Moderate \\
\hline Pre-Execution & $\begin{array}{l}\text { Music and } \\
\text { General Affairs, } \\
\text { Infrastructures, } \\
\text { Marketing, Pre-Event, }\end{array}$ & $\begin{array}{l}\text { Insignificant, } \\
\text { Minor, } \\
\text { Moderate, }\end{array}$ \\
\hline Execution & $\begin{array}{l}\text { Infrastructures, Music } \\
\text { and Creative, General } \\
\text { Affairs, Marketing, } \\
\text { Directors }\end{array}$ & 33 & $\begin{array}{l}\text { Minor, } \\
\text { Moderate, } \\
\text { Significant }\end{array}$ \\
\hline $\begin{array}{l}\text { Post- } \\
\text { Execution }\end{array}$ & $\begin{array}{l}\text { Infrastructures } \\
\text { Menerairs, }\end{array}$ & 3 & Minor, Moderate \\
\hline
\end{tabular}

According to the six stages of organizing an event determined by the author, based on the interviews, discussions and observations, potential risks are determined in every stage. Every risks and severity are presented along with the responsible division. There are total 78 potential risks in organizing the event through the six steps. Table 4 shows the summary of the findings. The analysis is then submitted to the experts for validation. After collecting the quantitative data regarding the probability and impact of the potential risks, recommendation for risk mitigations are made in every potential risks. There are six ways to respond to the risks which are risks transfer, defer, reduce, accept, avoid and share [4]. Upon validation process, the data of probability and impact table is then discussed among the committee through every division. However, due to the time limitation, the evaluation of the risk management design is applied only from pre-execution to post-execution phase.

The designed risk assessment is submitted to the committee to be a guidance in facing possible risks when conducting the Light up Charity concert, based on the experts' judgment through Delphi method. Active involvement from the directors is requested, hence the formulated document can contribute to significant results in the outcome. In regular meeting amongst all parties including directors, committees, performance, third parties, the risk mitigation plan shall be act as a guideline to reduce the potential risks. In the execution process, on the concert day, the author was present to observe directly any potential risks happened. All event is then documented and listed whether it occurred in the concert, upon the risk assessment recommendation. In order to see the success rate after implementing the risk management design plan for the concert, the author compared the result with the previous homogeneous concerts. The analysis would be based on simple calculation of which comparing total prevented potential risks to total potential risks. Table 5 summarizes the success rate in comparison with previous homogeneous concerts. The success rate is defined as below formula:

$$
\text { Success Rate }=\frac{\text { Total Prevented Potential Risks }}{\text { Total Potential Risks }} \times 100 \%
$$

TABLE V. COMPARISON OF SUCCESS RATES

\begin{tabular}{|l|l|l|l|}
\hline \multicolumn{1}{|c|}{ Concert } & Location & Visitors & $\begin{array}{l}\text { Success } \\
\text { Rate }\end{array}$ \\
\hline OH LPMI Concert & Bandung & 400 & $51 \%$ \\
\hline Classic Hymns 1 concert & Bandung & 500 & $57 \%$ \\
\hline Classic Hymns 2 concert & Bandung & 1.000 & $54 \%$ \\
\hline Classic Hymns 3 concert & Bandung & 1.000 & $54 \%$ \\
\hline Light up Charity Concert & Bandung & 3.000 & $76 \%$ \\
\hline
\end{tabular}

As can be seen from the Table 5, the success rate of this concert has shown improvements compared to the last four homogeneous concerts which on average obtained 54\% success rate. This means that by designing and applying the risk management system to musical concerts, it can help the 
committees to reduce the possible risks in every phase and gained the success rate to $76 \%$. The result has shown significant improvement in managing musical project through risk management and project management concept. This result has shown considerable result that in implementing musical concerts project, particularly with less than 3.000 visitors, risk management can play important role in creating successful concert, especially on concerts which committees and performers are mostly volunteers. From this study it can also be suggested for directors or managers in implementing music concerts as a business, with visitors less than 3.000, the importance for the organizing committees to also include risk assessment in their project planning. The traditional approach of which use disintegrated method in every functional sections and does not take into account risk management, shall indeed adapt risk management framework in the project development processes. Hence, it is expected that these dual approach can solve to reduce potential risks and problems which can increase success rate of the concert project.

\section{CONCLUSION}

According to the findings, there are 78 sources of potential risks from the phase of pre-planning, planning, organizing, preexecution, execution and post-execution with the various probabilities and impact from experts' opinion after going through the Delphi method. Strategies are delivered and recommended to prepare for risk of potentially disruptive risks by reducing probability, risk-averse, accept risk, transfer the risk and reduce the impact. It was found that the number of potential risks examined by the authors along with experts' opinion are able to overcome the potential risks and resulting the success rate of $73 \%$, compared to the four previous similar concerts were observed by the authors which have an average success rate of only 54\%. Event organizers must take into account the risks that they are facing in organizing musical concerts. This study will help managers and directors of event organizers to implement the event smoothly and obtain the higher success rate in the future events. Conceptual framework of AS/NZS 4360:2004 will be able to present clear guidance for all the committees, to formulate and resolute the risks mitigation plans. This study is aimed to be guidance in designing risk management system for private, small, and medium sized concerts. The potential outcomes on this study might be not comprehensively discussed due to the time limitation of the study. Hence, further observations and discussion to enhance the design is needed for better accuracy. Large sized concerts (>3.000 visitors) and outdoor concerts are not discussed in this study. This study can facilitate future studies as a benchmark to formulate the risk management design for such type of concerts. The study limits the observation in the concert of "Light up our Children's Future!" which was conducted in the area of Bandung, Indonesia. Size of the musical concerts is limited from 100 to 3.000 visitors per show as discussed in the previous chapter. The concert in this study is limited to indoor concerts. Outdoor concerts must have different complexities compared to indoor concerts since outdoor concerts might need more aspects to be considered such as the risk of the weather, humidity, and land environment. Hence, further research directions are to test the model in the future homogeneous concerts, expand the scope into concerts that take place in outdoor venues, or concerts that have total visitors of more than 3.000.

\section{REFERENCES}

[1] E. Ronchi. (2016). Modelling Large-Scale Evacuation of Music Festivals: Case Studies in Fire Safety. Available: http://ac.els-

cdn.com/S2214398X15300066/1-s2.0-

S2214398X15300066-main.pdf? tid=01804538-

20b2-11e6-b853-

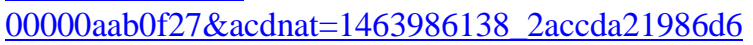
285a2dd65f7912c3eaf

[2] S. Carroll. (2012). Risk-Preparedness and Mitigation for Live Events.

[3] Standards Autralia, Handbook: Risk Management Guidelines Companion to AS/NZS 4360:2004: Standard Australia / Standard New Zealand, 2004.

[4] T. Merna and F. Al-Thani, Corporate Risk Management: 2nd Edition. England: John Wiley \& Sons Ltd., 2008.

[5] H. A. Linstone and M. Turoff, The Delphi Method: Techniques and Applications: Addison-Wesley Publishing Company, 2002.

[6] Event Safety Management Guide, 2011.

[7] J. R. Meredith and S. J. Mantel, Project Management: A Managerial Approach: John Wiley \& Sons, 2009.

[8] Oxford Dictionaries, ed, 2016.

[9] B. Audstone. (2012). What is the Difference between Event and Project? Available: http://www.quora.com/Project-Management/What-isthe-difference-between-event-and-project-they-arenot-mutually-exclusive-but-the-software-sites-makesthem-look-like-they-are 
TABLE IV. POTENTIAL Risks AND RISK LEVEL IN EVERy PHASE

\begin{tabular}{|c|c|c|c|c|c|c|c|}
\hline Phase & Activity & Potential Risk & $\begin{array}{l}\text { Potential } \\
\text { Risk } \\
\text { Code }\end{array}$ & $\begin{array}{c}\text { Average } \\
\text { Probability }\end{array}$ & $\begin{array}{l}\text { Average } \\
\text { Impact }\end{array}$ & $\begin{array}{l}\text { Weighted } \\
\text { Average }\end{array}$ & Risk Level \\
\hline $\begin{array}{l}\text { Pre- } \\
\text { Planning }\end{array}$ & Committee analysis and planning & $\begin{array}{l}\text { Not every committee can } \\
\text { come to the meeting that } \\
\text { can lead to disintegration } \\
\text { among the committee and } \\
\text { slowing the project. }\end{array}$ & PR1 & 3 & 2.82 & 8.46 & Minor \\
\hline $\begin{array}{l}\text { Pre- } \\
\text { Planning }\end{array}$ & $\begin{array}{l}\text { Formulizing direction and } \\
\text { objective of the concert. }\end{array}$ & $\begin{array}{l}\text { Does not aligned with the } \\
\text { church's / director's } \\
\text { objective. }\end{array}$ & PR2 & 2.55 & 3.73 & 9.51 & Minor \\
\hline $\begin{array}{l}\text { Pre- } \\
\text { Planning }\end{array}$ & $\begin{array}{l}\text { Feasibility study regarding the } \\
\text { project. }\end{array}$ & $\begin{array}{l}\text { Not every aspect is } \\
\text { assessed in the feasibility } \\
\text { study. }\end{array}$ & PR3 & 3 & 3.27 & 9.81 & Minor \\
\hline Planning & $\begin{array}{l}\text { Budget estimation and source of } \\
\text { funds. }\end{array}$ & $\begin{array}{l}\text { Overestimate or } \\
\text { underestimate in budget } \\
\text { planning. }\end{array}$ & PR4 & 3.55 & 3.45 & 12.25 & Moderate \\
\hline Planning & $\begin{array}{l}\text { Determine the schedule for } \\
\text { regular meeting with directors. }\end{array}$ & $\begin{array}{l}\text { Schedule mismatch } \\
\text { amongst committee. }\end{array}$ & PR5 & 3.09 & 3.36 & 10.38 & Moderate \\
\hline Organizing & Recruitment of field committee. & $\begin{array}{l}\text { Incompetent committee, } \\
\text { lack of volunteers. }\end{array}$ & PR6 & 2.45 & 3.64 & 8.92 & Minor \\
\hline Organizing & Give direction for the committee. & $\begin{array}{l}\text { Not every committee can } \\
\text { come. }\end{array}$ & PR7 & 3.73 & 3 & 11.19 & Moderate \\
\hline Organizing & $\begin{array}{l}\text { Distribute roles and } \\
\text { responsibilities }\end{array}$ & $\begin{array}{l}\text { Some personnel have } \\
\text { excessive roles and } \\
\text { responsibilities that can } \\
\text { disrupt the project }\end{array}$ & PR8 & 3.18 & 3 & 9.54 & Minor \\
\hline $\begin{array}{l}\text { Pre- } \\
\text { execution }\end{array}$ & $\begin{array}{l}\text { Conduct regular performance } \\
\text { practice }\end{array}$ & Late in rehearsing & PR9 & 4 & 2.82 & 11.28 & Moderate \\
\hline $\begin{array}{l}\text { Pre- } \\
\text { execution }\end{array}$ & $\begin{array}{l}\text { Conduct regular performance } \\
\text { practice }\end{array}$ & $\begin{array}{l}\text { Some personnel suddenly } \\
\text { cannot attend the practice }\end{array}$ & PR10 & 3.73 & 3.09 & 11.53 & Moderate \\
\hline $\begin{array}{l}\text { Pre- } \\
\text { execution }\end{array}$ & $\begin{array}{l}\text { Conduct regular performance } \\
\text { practice }\end{array}$ & $\begin{array}{l}\text { No available room for } \\
\text { practice }\end{array}$ & PR11 & 2.36 & 2.55 & 6.02 & Minor \\
\hline $\begin{array}{l}\text { Pre- } \\
\text { execution }\end{array}$ & $\begin{array}{l}\text { Conceptualizing the arrangement } \\
\text { and the whole concert } \\
\text { performance }\end{array}$ & $\begin{array}{l}\text { Only one arranger } \\
\text { conducts the arrangement } \\
\text { within very tight } \\
\text { schedule. }\end{array}$ & PR12 & 3.18 & 2.27 & 7.22 & Minor \\
\hline $\begin{array}{l}\text { Pre- } \\
\text { execution }\end{array}$ & Conduct rehearsal & $\begin{array}{l}\text { Not everyone can come } \\
\text { to the rehearsal }\end{array}$ & PR13 & 3.27 & 3.18 & 10.40 & Moderate \\
\hline $\begin{array}{l}\text { Pre- } \\
\text { execution }\end{array}$ & Conduct rehearsal & $\begin{array}{l}\text { Late in starting the } \\
\text { rehearsal }\end{array}$ & PR14 & 3.64 & 2.64 & 9.61 & Minor \\
\hline $\begin{array}{l}\text { Pre- } \\
\text { execution }\end{array}$ & $\begin{array}{l}\text { Conceptualizing the design of the } \\
\text { stage and the interiors }\end{array}$ & $\begin{array}{l}\text { Performers and designers } \\
\text { do not conduct } \\
\text { coordination meeting } \\
\text { regarding the stage } \\
\text { design, hence creating } \\
\text { disintegration between } \\
\text { the design and the } \\
\text { performance. }\end{array}$ & PR15 & 3.36 & 3.27 & 10.99 & Moderate \\
\hline $\begin{array}{l}\text { Pre- } \\
\text { execution }\end{array}$ & Conduct final rehearsal & $\begin{array}{l}\text { Late in starting the } \\
\text { rehearsal }\end{array}$ & PR16 & 3.55 & 2.82 & 10.01 & Minor \\
\hline $\begin{array}{l}\text { Pre- } \\
\text { execution }\end{array}$ & Conduct final rehearsal & Late in sound check. & PR17 & 3.45 & 3.45 & 11.90 & Moderate \\
\hline $\begin{array}{l}\text { Pre- } \\
\text { execution }\end{array}$ & $\begin{array}{l}\text { Handle the registration and ticket } \\
\text { payment administration. }\end{array}$ & Tickets lacking & PR18 & 2.73 & 3.36 & 9.17 & Minor \\
\hline $\begin{array}{l}\text { Pre- } \\
\text { execution }\end{array}$ & $\begin{array}{l}\text { Handle the registration and ticket } \\
\text { payment administration. }\end{array}$ & Excess tickets & PR19 & 3 & 2.82 & 8.46 & Minor \\
\hline $\begin{array}{l}\text { Pre- } \\
\text { execution }\end{array}$ & $\begin{array}{l}\text { Handling administration with } \\
\text { media partners for external } \\
\text { publication. }\end{array}$ & $\begin{array}{l}\text { Late in publishing the } \\
\text { advertisements externally }\end{array}$ & PR20 & 2.73 & 3.09 & 8.44 & Minor \\
\hline $\begin{array}{l}\text { Pre- } \\
\text { execution }\end{array}$ & $\begin{array}{l}\text { Handling administration with } \\
\text { sound system provider. }\end{array}$ & $\begin{array}{l}\text { Lack of coordination in } \\
\text { technical specifications, } \\
\text { power, brand, quality and } \\
\text { condition of the }\end{array}$ & PR21 & 2.91 & 4.09 & 11.90 & Moderate \\
\hline
\end{tabular}


TABLE IV. Potential Risks ANd Risk LeVEl In EVERy Phase

\begin{tabular}{|c|c|c|c|c|c|c|c|}
\hline Phase & Activity & Potential Risk & $\begin{array}{l}\text { Potential } \\
\text { Risk } \\
\text { Code }\end{array}$ & $\begin{array}{c}\text { Average } \\
\text { Probability }\end{array}$ & $\begin{array}{c}\text { Average } \\
\text { Impact }\end{array}$ & $\begin{array}{l}\text { Weighted } \\
\text { Average }\end{array}$ & Risk Level \\
\hline & & equipment. & & & & & \\
\hline $\begin{array}{l}\text { Pre- } \\
\text { execution }\end{array}$ & $\begin{array}{l}\text { Take photos regarding the whole } \\
\text { activities in the concert, from pre- } \\
\text { planning to post execution. }\end{array}$ & $\begin{array}{l}\text { Lack of documentation } \\
\text { committee. }\end{array}$ & PR22 & 2.64 & 2.36 & 6.23 & Minor \\
\hline $\begin{array}{l}\text { Pre- } \\
\text { execution }\end{array}$ & $\begin{array}{l}\text { Contact the main guest star and } \\
\text { his/her needs prior performing. }\end{array}$ & $\begin{array}{l}\text { The guest star requested } \\
\text { several things that is } \\
\text { difficult to be fulfilled. }\end{array}$ & PR23 & 3.18 & 3.64 & 11.58 & Moderate \\
\hline $\begin{array}{l}\text { Pre- } \\
\text { execution }\end{array}$ & $\begin{array}{l}\text { Plan and organize the needs of } \\
\text { accommodation and } \\
\text { transportation for the guest stars. }\end{array}$ & $\begin{array}{l}\text { The guest star does not } \\
\text { use the provided facilities } \\
\text { by the committee. }\end{array}$ & PR24 & 2.91 & 2.45 & 7.13 & Minor \\
\hline $\begin{array}{l}\text { Pre- } \\
\text { execution }\end{array}$ & $\begin{array}{l}\text { Handling the venue utilization } \\
\text { administrations. }\end{array}$ & $\begin{array}{l}\text { The venue is fully } \\
\text { booked, hence need to } \\
\text { find another venue. }\end{array}$ & PR25 & 2.64 & 3.91 & 10.32 & Moderate \\
\hline $\begin{array}{l}\text { Pre- } \\
\text { execution }\end{array}$ & $\begin{array}{l}\text { Plan for on-site ticketing for } \\
\text { visitors that cannot obtain the } \\
\text { ticket in prior days, but come in } \\
\text { the D-day. }\end{array}$ & $\begin{array}{l}\text { Differences on } \\
\text { unoccupied seats with } \\
\text { total on the spot visitors. }\end{array}$ & PR26 & 2.82 & 2.91 & 8.21 & Minor \\
\hline $\begin{array}{l}\text { Pre- } \\
\text { execution }\end{array}$ & $\begin{array}{l}\text { Stewarding protocol for regular } \\
\text { and VIP visitors. }\end{array}$ & $\begin{array}{l}\text { Stewards does not fully } \\
\text { understand the protocols. }\end{array}$ & PR27 & 3 & 2.73 & 8.19 & Minor \\
\hline $\begin{array}{l}\text { Pre- } \\
\text { execution }\end{array}$ & $\begin{array}{l}\text { Conduct survey to the planned } \\
\text { venue. }\end{array}$ & No survey conducted. & PR28 & 2.55 & 3.91 & 9.97 & Minor \\
\hline $\begin{array}{l}\text { Pre- } \\
\text { execution }\end{array}$ & $\begin{array}{l}\text { Conduct survey to the planned } \\
\text { venue. }\end{array}$ & $\begin{array}{l}\text { Electrical specification of } \\
\text { the venue does not match } \\
\text { with the sound system } \\
\text { providers' needs. }\end{array}$ & PR29 & 3.09 & 4.09 & 12.64 & Moderate \\
\hline $\begin{array}{l}\text { Pre- } \\
\text { execution }\end{array}$ & $\begin{array}{l}\text { Provide disaster safety systems (if } \\
\text { needed) such as fire extinguisher, } \\
\text { ambulance contact, etc. }\end{array}$ & Does not managed. & PR30 & 3 & 3.64 & 10.92 & Moderate \\
\hline $\begin{array}{l}\text { Pre- } \\
\text { execution }\end{array}$ & $\begin{array}{l}\text { Provide life safety systems (if } \\
\text { needed) such as oxygen tubes, } \\
\text { life buoy, etc. }\end{array}$ & Does not managed. & PR31 & 3.09 & 3.64 & 11.25 & Moderate \\
\hline $\begin{array}{l}\text { Pre- } \\
\text { execution }\end{array}$ & $\begin{array}{l}\text { Provide handy talky (HT) for } \\
\text { facilitating committee's } \\
\text { communication (if needed). }\end{array}$ & Does not managed. & PR32 & 2.64 & 2.91 & 7.68 & Minor \\
\hline $\begin{array}{l}\text { Pre- } \\
\text { execution }\end{array}$ & $\begin{array}{l}\text { Organize and plan the dressing } \\
\text { room for committee and } \\
\text { performers. }\end{array}$ & Does not managed. & PR33 & 3.09 & 2.91 & 8.99 & Minor \\
\hline $\begin{array}{l}\text { Pre- } \\
\text { execution }\end{array}$ & $\begin{array}{l}\text { Survey and contact the sound } \\
\text { system provider. }\end{array}$ & Does not conducted. & PR34 & 2.36 & 4.36 & 10.29 & Moderate \\
\hline $\begin{array}{l}\text { Pre- } \\
\text { execution }\end{array}$ & $\begin{array}{l}\text { Coordinate with the musical } \\
\text { performers regarding the } \\
\text { specification of sound system that } \\
\text { is needed. }\end{array}$ & $\begin{array}{l}\text { Mismatch regarding the } \\
\text { needs of musical } \\
\text { performers, particularly } \\
\text { in tools and equipment, } \\
\text { with the sound system } \\
\text { provided by the } \\
\text { providers. }\end{array}$ & PR35 & 3.36 & 4.36 & 14.65 & Moderate \\
\hline $\begin{array}{l}\text { Pre- } \\
\text { execution }\end{array}$ & $\begin{array}{l}\text { Coordinate with the musical } \\
\text { performers regarding the } \\
\text { specification of sound system that } \\
\text { is needed. }\end{array}$ & $\begin{array}{l}\text { Mismatch in electrical } \\
\text { specification. }\end{array}$ & PR36 & 3.09 & 4.18 & 12.92 & Moderate \\
\hline $\begin{array}{l}\text { Pre- } \\
\text { execution }\end{array}$ & $\begin{array}{l}\text { Anticipate visitors with special } \\
\text { request, but not disabilities. }\end{array}$ & $\begin{array}{l}\text { Visitor that bring babies, } \\
\text { animals, etc. that needs } \\
\text { special attention. }\end{array}$ & PR37 & 1.91 & 2.18 & 4.16 & Insignificant \\
\hline $\begin{array}{l}\text { Pre- } \\
\text { execution }\end{array}$ & $\begin{array}{l}\text { Anticipate protocols for visitors } \\
\text { with human disabilities. }\end{array}$ & Does not managed. & PR38 & 3 & 2.09 & 6.27 & Minor \\
\hline $\begin{array}{l}\text { Pre- } \\
\text { execution }\end{array}$ & $\begin{array}{l}\text { Plan for safety induction to all } \\
\text { committee and directors in the } \\
\text { venue. }\end{array}$ & Does not managed. & PR39 & 3 & 3.55 & 10.65 & Moderate \\
\hline
\end{tabular}


TABLE IV. Potential Risks ANd Risk LeVEl In EVERy Phase

\begin{tabular}{|c|c|c|c|c|c|c|c|}
\hline Phase & Activity & Potential Risk & $\begin{array}{l}\text { Potential } \\
\text { Risk } \\
\text { Code }\end{array}$ & $\begin{array}{c}\text { Average } \\
\text { Probability }\end{array}$ & $\begin{array}{l}\text { Average } \\
\text { Impact }\end{array}$ & $\begin{array}{l}\text { Weighted } \\
\text { Average }\end{array}$ & Risk Level \\
\hline $\begin{array}{l}\text { Pre- } \\
\text { execution }\end{array}$ & $\begin{array}{l}\text { Conduct survey and coordination } \\
\text { with the lighting system provider. }\end{array}$ & Does not managed. & PR40 & 2.82 & 3.55 & \begin{tabular}{|c|c|}
10.01 \\
\end{tabular} & Minor \\
\hline $\begin{array}{l}\text { Pre- } \\
\text { execution }\end{array}$ & $\begin{array}{l}\text { Design and create publication in } \\
\text { various medias. }\end{array}$ & $\begin{array}{l}\text { Late in publishing the } \\
\text { advertisements. }\end{array}$ & PR41 & 2.36 & 3.36 & 7.93 & Minor \\
\hline $\begin{array}{l}\text { Pre- } \\
\text { execution }\end{array}$ & $\begin{array}{l}\text { Socialize the program (oral } \\
\text { presentation) to various potential } \\
\text { visitors }\end{array}$ & Does not managed well. & PR42 & 2.36 & 3.09 & 7.29 & Minor \\
\hline Execution & $\begin{array}{l}\text { Conduct briefing and safety } \\
\text { induction. }\end{array}$ & Does not managed. & PR43 & 3 & 2.91 & 8.73 & Minor \\
\hline Execution & $\begin{array}{l}\text { Conduct briefing and safety } \\
\text { induction. }\end{array}$ & $\begin{array}{l}\text { Not every committee and } \\
\text { directors come to the } \\
\text { briefing and safety } \\
\text { induction. }\end{array}$ & PR44 & 3.09 & 3.64 & 11.25 & Moderate \\
\hline Execution & Anticipate if visitors come late. & $\begin{array}{l}\text { No contingency plan for } \\
\text { late coming visitors. }\end{array}$ & PR45 & 2.64 & 3 & 7.92 & Minor \\
\hline Execution & $\begin{array}{l}\text { Prepare the layout and emergency } \\
\text { evacuation route }\end{array}$ & Does not managed. & PR46 & 3 & 3 & 9.00 & Minor \\
\hline Execution & $\begin{array}{l}\text { Prepare route map for enter and } \\
\text { exit of visitor. }\end{array}$ & Does not managed. & PR47 & 3.18 & 3.55 & 11.29 & Moderate \\
\hline Execution & $\begin{array}{l}\text { Estimate the parking area for } \\
\text { vehicles. }\end{array}$ & $\begin{array}{l}\text { Insufficient parking } \\
\text { spaces. }\end{array}$ & PR48 & 3.27 & 1.91 & 6.25 & Minor \\
\hline Execution & $\begin{array}{l}\text { Provide waste disposal storage } \\
\text { inside and outside the venue. }\end{array}$ & $\begin{array}{l}\text { Insufficient waste } \\
\text { storages in the venue. }\end{array}$ & PR49 & 2.73 & 2.18 & 5.95 & Minor \\
\hline Execution & $\begin{array}{l}\text { Organize and plan the lighting } \\
\text { systems detail specifications in } \\
\text { the venue. }\end{array}$ & $\begin{array}{l}\text { Electric specifications do } \\
\text { not match with the venue. }\end{array}$ & PR50 & 2.27 & 4.64 & 10.53 & Moderate \\
\hline Execution & $\begin{array}{l}\text { Organize and plan the lighting } \\
\text { systems detail specifications in } \\
\text { the venue. }\end{array}$ & $\begin{array}{l}\text { Lighting system does not } \\
\text { align with the } \\
\text { performance in stage with } \\
\text { the performers. }\end{array}$ & PR51 & 2.91 & 3.36 & 9.78 & Minor \\
\hline Execution & $\begin{array}{l}\text { Organize and plan the lighting } \\
\text { systems detail specifications in } \\
\text { the venue. }\end{array}$ & $\begin{array}{l}\text { Lamps or lighting system } \\
\text { broke down. }\end{array}$ & PR52 & 2.27 & 4.73 & 10.74 & Moderate \\
\hline Execution & $\begin{array}{l}\text { Create rule for visitors when } \\
\text { taking pictures or videos. }\end{array}$ & $\begin{array}{l}\text { No rule for visitors when } \\
\text { taking picture or videos } \\
\text { which can create potential } \\
\text { mess in the venue. }\end{array}$ & PR53 & 2.73 & 3 & 8.19 & Minor \\
\hline Execution & $\begin{array}{l}\text { Ensure that electricity power is } \\
\text { backed up well, such as installing } \\
\text { back up electric generator. }\end{array}$ & $\begin{array}{l}\text { Power failure with no } \\
\text { other backup generators. }\end{array}$ & PR54 & 4.09 & 4.45 & 18.20 & Significant \\
\hline Execution & $\begin{array}{l}\text { Ensure that the stage structure is } \\
\text { safe with the performers' } \\
\text { performance. }\end{array}$ & The stage collapsed. & PR55 & 2.27 & 5 & 11.35 & Moderate \\
\hline Execution & $\begin{array}{l}\text { Ensure that the sanitation system } \\
\text { is maintained well. }\end{array}$ & $\begin{array}{l}\text { Dirty toilets / sanitation } \\
\text { systems. }\end{array}$ & PR56 & 2.55 & 2.73 & 6.96 & Minor \\
\hline Execution & $\begin{array}{l}\text { Manage potential conflict } \\
\text { amongst visitors, overcrowding, } \\
\text { etc. }\end{array}$ & $\begin{array}{l}\text { Visitors carrying } \\
\text { weapons (guns, knives, } \\
\text { arms, etc.) }\end{array}$ & PR57 & 2 & 4.09 & 8.18 & Minor \\
\hline Execution & $\begin{array}{l}\text { Manage potential conflict } \\
\text { amongst visitors, overcrowding, } \\
\text { etc. }\end{array}$ & $\begin{array}{l}\text { Visitors feeling unwell / } \\
\text { sick }\end{array}$ & PR58 & 2.36 & 2.36 & 5.57 & Minor \\
\hline Execution & $\begin{array}{l}\text { Manage potential conflict } \\
\text { amongst visitors, overcrowding, } \\
\text { etc. }\end{array}$ & Conflict among visitors & PR59 & 2.36 & 4.18 & 9.86 & Minor \\
\hline Execution & $\begin{array}{l}\text { Manage potential conflict } \\
\text { amongst visitors, overcrowding, } \\
\text { etc. }\end{array}$ & $\begin{array}{l}\text { Loss of visitors' } \\
\text { belongings }\end{array}$ & PR60 & 3 & 1.91 & 5.73 & Minor \\
\hline Execution & $\begin{array}{l}\text { Manage potential conflict } \\
\text { amongst visitors, overcrowding, } \\
\text { etc. }\end{array}$ & Overcrowding & PR61 & 3.36 & 3.36 & 11.29 & Moderate \\
\hline
\end{tabular}


TABLE IV. Potential Risks ANd Risk LeVEl In EVERy Phase

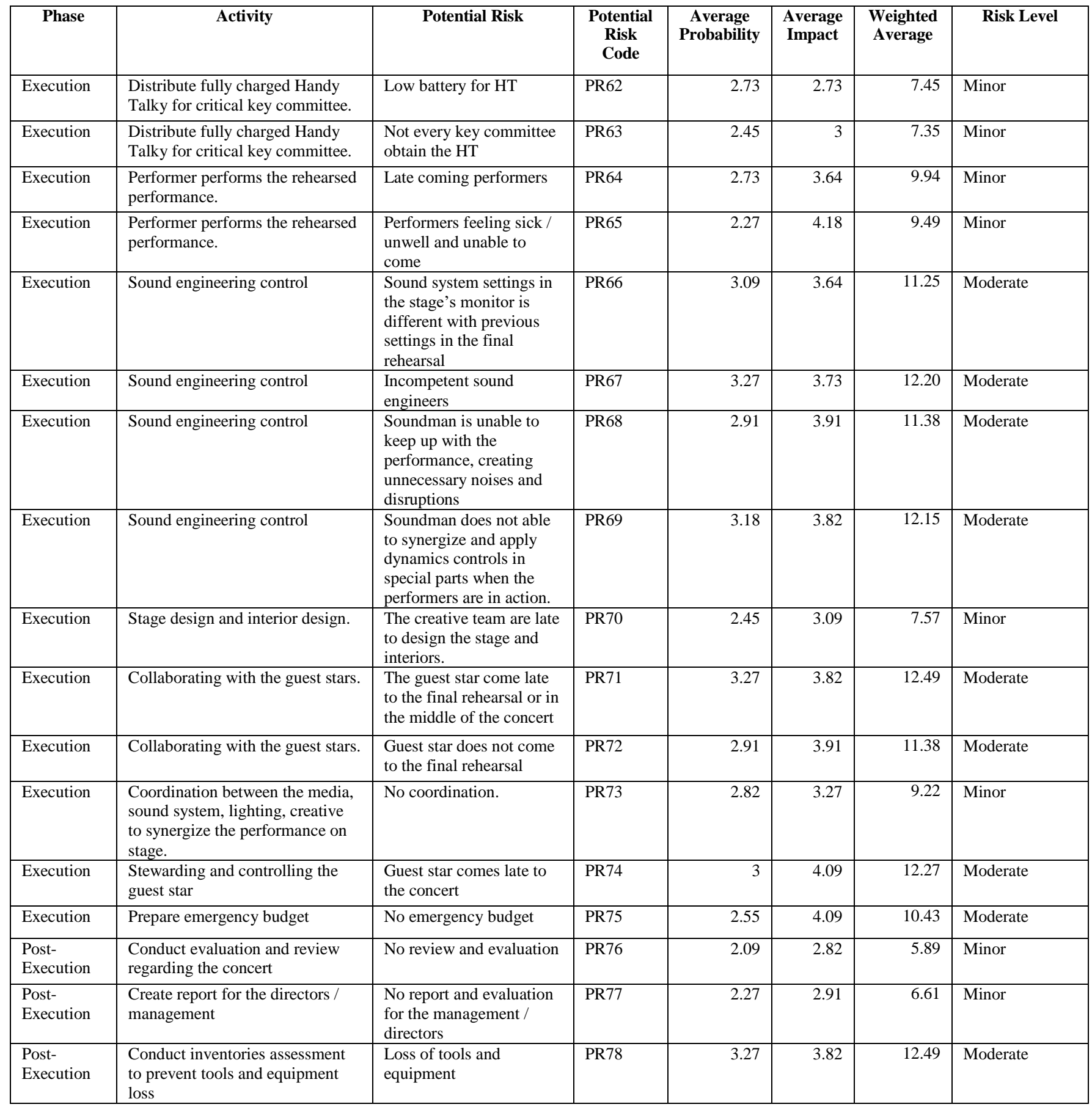

